Garant, M. (2019). Current Trends in Translation Teaching and Learning 2020. Current Trends in Translation Teaching and Learning E, 7, 1 - 3. 10.51287/cttl_e_2020_1_mikel_garant.pdf

\title{
Current Trends in Translation Teaching and Learning 2020
}

Mikel Garant

Beijing Institute of Technology, Zhuhai

Dear Readers,

2020 has been a strange year. Because of COVID-19, teachers and learners all over the globe have had their classes online for the first time in history, affecting everyone's lives. This is Volume 7 of Current Trends in Translation Teaching and Learning E. This volume includes articles from Australia, Indonesia, China, Spain, Slovenia, the United Kingdom, Hong Kong, Italy, Poland, Taiwan, Spain, and Finland.

I would like to thank Lixing Liang, from Huazhong University of Science and Technology, China, for establishing a book review section. He is now Book Reviews Editor. If you would like to submit a book review, please feel free to contact him via our website.

This year, CTTL E became member of Crossref, the member organization for scholarly publishers that helps the community find, cite, link, and assess scholarly content through the use of persistent identifiers and metadata. Our journal can now issue each article a Digital Object Identifier (DOI).

I would like to thank all the double-blind article reviewers for their hard work. In cases where the writers preferred, university names have not been translated into English. The following members of the Editorial Review Board reviewed articles for the 2020 edition:

ALEXANDRA ALBUQUERQUE, Polytechnic of Porto, Portugal

MARIA BRANDER DE LA IGLESIA, University of Salamanca, Spain

MARIA PILAR CASTILLO, University of Córdoba, Spain

ELENA DE LA COVA, Universidad Pablo de Olavide, Spain

MARÍA DEL MAR HARO-SOLER, University of Granada, Spain

SANEL HADŽIAHMETOVIĆ JURIDA, University of Tuzla, Bosnia and Herzegovina

RALPH KRÜGER, Cologne University of Applied Sciences, Germany

IGOR LAKIĆ, University of Montenegro, Montenegro

LINXIN LIANG, Huazhong University of Science and Technology, China

RUDY LOOCK, University of Lille, France

IULIA MIHALACHE, University of Quebec in Outaouais, Canada

TANJA PAVLOVIĆ, University of Tuzla, Bosnia and Herzegovina

ENCARNCIÓN POSTIGO PINAZO, University of Málaga, Spain 
Garant, M. (2019). Current Trends in Translation Teaching and Learning 2020. Current Trends in Translation Teaching and Learning E, 7, 1-3.10.51287/cttl_e_2020_1_mikel_garant.pdf

LILIK ISTIQOMAH, IAIN Surakarta, Indonesia

MARIÁN MORÓN MARTIN, Universidad Pablo de Olavide, Spain

TANJA PAVLOVIĆ, University of Tuzla, Bosnia and Herzegovina

PING YANG, Western Sydney University, Australia

PABLO SALVADOR PEREZ PEREZ, University of Malaga, Spain

TAO YOULAN, Fudan University, China

The first article, written by Juho Suokas, from the University of Eastern Finland, addresses usercentered translation (UCT). It examines how translation students experience using two UCT methods: personas and heuristic evaluation. The next article by Chen-En Ho, from Queen's University Belfast, addresses how action research can be used to motivate beginning interpreting students to overcome challenges in interpreting practice via translation activities. Beata Piecychna, from the University of Białystok, Poland, focuses on translation trainees' views on the implementation of projects during which students are tasked with simulating professional translational activities specific to the translation industry.

The article by Marco Zappatore, from the University of Salento, Italy, discusses how a Simulated Translation Agency (STA) can use a holistic approach premise to motivate students to manage a fictional company according to a professional translation workflow. Urszula Paradowska, from the Jacob of Paradies University, Poland, presents a longitudinal study of how students can increase their digital literacy skills. It includes a collection of web-based resources primarily for Polish - English translation. After that, an article by Cheryl Wei-yu Che, from National Taipei University of Business, Taiwan, explores how Google Translate can be used to help its users accomplish a translation task utilizing reflexive pedagogy.

Francisco J. Vigier-Moreno, from Universidad Pablo de Olavide of Seville, Spain, discusses challenges in business interpreter training for an undergraduate English-Spanish program and increasing autonomous practice both in groups and individually. Lyu Wang, from Hunan Normal University, China, and Xiangling Wang, from Hunan University, China, evaluated students' translation quality through two different approaches to examine the effects of marking method on the assessment of literary translations in a pedagogical context.

Lyu Wang, from Changsha University of Science and Technology, China, and Xiangling Wang, from Hunan University, contributed an article comparing evaluation based on either error analysis or a scale method when applied to literary translation. Melita Koletnik. from the University of Maribor, Slovenia, explores the potential and limitations of employing translation exercises in the additional language teaching (ALT) of future translators, and its effect on the development of students' emerging translation competence. 
María Luisa Rodríguez Muñoz, from the University of Córdoba, Spain, examines developing social skills when training Spanish translation using project-based method of group learning. Muhammad Aminuddin, Ping Yang, and Hiromi Muranaka-Vuletich, Western Sydney University, Australia, investigated translations of Islamic terms from Indonesian to English.

In addition to these refereed, academic articles, this volume incudes two book reviews. Yingbin Sun, from Huazhong University of Science and Technology, China, and Linxin Liang, from Huazhong University of Science and Technology, China, reviewed Barbara Lewandowska-Tomaszczyk's edited collection Cultural Conceptualizations in Translation and Language Applications. Yan Liu, from Beijing Electronic Science and Technology Institute, China, and Jianning Zheng, from Beijing Normal University, China, reviewed Roberto A. Valdeón's edited collection Chinese Translation Studies in the 21st Century: Current Trends and Emerging Perspectives.

We always welcome feedback. Thank you to Victoria Miller for her assistance and proofreading. If you have any questions or comments or would like to submit an article or book review for the 2021 edition, please do not hesitate to contact Current Trends in Translation Teaching and Learning E via our webpage. We hope you enjoy our 2020 edition. 